\title{
Ovaprim Abrogates Expression of GnRH Receptor- II in the Indian Catfish
}

\author{
Munmun Chowdhury, Aniruddha Chatterjee, Anushree Mondal \& Urmi Chatterji (Corresponding author) \\ Department of Zoology, University of Calcutta, 35 Ballygunge Circular Road, Kolkata-700 019, India \\ Tel: 91-933-937-6535_E-mail: urmichatterji@gmail.com
}

Research funded by University Grants Commission, New Delhi, India, to UC; Dr. A. Sharma and Dr. S. Ghosh to M.C., and Department of Science and Technology, New Delhi, India, for infrastructure support through the DST-FIST programme

\begin{abstract}
Hormone-induced breeding of fish has been effectively achieved with ovaprim, a salmon GnRH analog, in several teleost fish but not quite successfully in the Indian catfish. In order to analyze the rationale behind ovaprim ineffectiveness in this species, we investigated the effect of ovaprim injection on the GnRH receptors of the ovary and other extra-pituitary organs, since GnRH receptors are known to be over-expressed during spawning. RT-PCR analysis revealed that the GnRH receptor-II is present not only in the ovary, but also in the testis, liver and heart tissues of the catfish. However, the expression of the receptor declined in a time-dependent manner in response to ovaprim injection in all the above tissues. Concomitant changes were observed in the histology of the ovary, which indicated a decrease in the number of the immature ovarian follicles, thus elucidating the rationale behind partial success of ovaprim-induced spawning in the Indian catfish, as compared to other teleosts.
\end{abstract}

Keywords: Catfish, Ovaprim, GnRH, Gonadotropin receptors, Ovary, Spawning

\section{Introduction}

The essential need to increase the supply of animal protein has prompted many countries to seek ways to augment the production of fish through the development of more effective techniques for fish culture (Rottmann et al., 1991). The high demand for fish fingerlings in the aquaculture industry has stimulated the need for artificial propagation of cultivable warm water fish. However, a major factor that constrains the speed and extent of development of fish culture has been the availability of "fish seed", viz., fry and fingerlings (Nwokoye et al., 2007). A common practice in the past had been to collect them from their natural sources like streams, estuaries, or coastal areas (Staff, 1983) but their occurrence became limited by the spawning period of the fish (usually short), meteorological and water conditions, and their vulnerability to predation. In addition, natural fry grounds are often distant from fish farming localities, leading to expensive transportation and heavy mortality of larvae and fry. Concomitantly, fish seed collected from natural habitat is usually composed of several species, some of which are unsuitable for culture. Since there is no easy method for separating the desirable ones from the others, the method did not prove to be an efficient one. Furthermore, water pollution due to rapid industrial development and the increasing use of insecticides may, in not too distant future, deplete natural spawning stocks and cause heavy mortality of larvae and fry (Dupree and Huner, 1984; Piper, 1989).

In order to ensure a reliable supply of quality fish seed, various techniques have been developed for breeding pond fish under controlled conditions. Where some methods require only elementary changes in environmental conditions, others require sexual segregation of mature specimens or substrates for attachment of eggs. The most sophisticated and efficient technique till date is the use of hormones to induce spawning (Staff, 1983; Richardson, 1988). Although the technique of induced spawning by hypophysation of cultivated fishes is still in its early stage of development, it has achieved various degrees of success in different countries and for different species of fish.

Since the 1990s, a drug known as ovaprim has been commonly used as a spawning hormone in fish breeding (Marte et al., 1987). Ovaprim, which is a combination of salmon GnRH analog combined with a dopamine agonist Domperidone, has proved to be extremely successful in breeding of carps with a spawning rate of about $100 \%$. In comparison, the success rate of spawning using GnRH analogs in other fishes are 100\% in Grouper (Epinephelus salmoides) (Kungvankij et al., 1986), about 99.7\% in Mullet (Mugil cephalus) (Lee et al., 1987), 
and 99\% in Milkfish (Channos chanos) (Kelley and Lee, 1986). However, there are a number of fish species that have great economic significance but do not reproduce spontaneously in captivity (Rottmann et al., 1991). These species are thus relatively less responsive to techniques involved in induced breeding. Catfish are a favorite food in India and Southeast Asia. Of the three species that are chiefly cultivated viz. Clarias batrachus, C. gariepinus and C. macrocephalus, the first and third are extensively cultured in Asia. Although C. batrachus breeds naturally in ponds, the efficiency and rate of induced spawning of catfish with ovaprim has been found to be less than 50\% (Thalathiah et al., 1988; Ngamvongchon et al., 1988), which is very low compared to that of carps. This study is an effort to analyze the reason behind the low success rate of spawning in catfish in response to ovaprim treatment.

It is well established that in vertebrates, gonadotropin-releasing hormones $(\mathrm{GnRH})$ act via $\mathrm{GnRH}$ receptors on target organs to regulate reproduction (Robinson et al., 2001). Thus, regulation of fish reproductive fecundity can be elucidated by analyzing the interaction and effect of GnRH analogs, such as ovaprim, on GnRH receptors. Several studies have reported different forms of GnRH receptors that have a wide spread distribution outside the brain, suggesting that in addition to their gonadotropin-releasing activity, they may also modulate the function of other organs that have direct and/or indirect roles in reproduction (Habibi et al., 1988; Habibi et al., 1989; Pati and Habibi, 1992). However, there is very sparse data regarding GnRH receptors in the Indian catfish. The present study analyzes the constitutive expression and tissue distribution of GnRH receptor-II in C. batrachus, and additionally their expression in response to ovaprim treatment.

\section{Materials and Methods}

\subsection{Animal model}

Healthy and adult specimens of $C$. batrachus, weighing $230 \pm 20$ gm, body length of $22-25 \mathrm{~cm}$, were collected from the local fish market. Fish were acclimatized to laboratory conditions and reared according to the Animal Care guidelines of University of Calcutta. Adult ovulatory female and male fish were used for the experiments. Water temperature varied according to the surrounding environmental temperature. Three fish were used for each dose or time point mentioned in the subsequent experiments for statistically significant data.

\subsection{Ovaprim administration}

Ovaprim was obtained from Syndel Laboratories Ltd., Canada, as a ready-to-use liquid in a standard dose. The volume injected was calculated by multiplying the weight of the fish by $0.5 \mathrm{ml} / \mathrm{kg}$, the amount recommended by the manufacturers for successful induced spawning of carps and other fish (Syndel International Inc.). Ovaprim was injected intramuscularly at the base of the dorsal fin in females. The control animals were sham injected. The injection was given at two intervals as per the manufacturer's instructions. Initially $0.125 \mathrm{ml} / \mathrm{kg}$ was injected, followed by a booster dose of $0.375 \mathrm{ml} / \mathrm{kg} 2$ hours after the first injection. The males were injected once with one-fourth the dose given to females, that is $0.125 \mathrm{ml} / \mathrm{kg}$. At the end of the experiment, fish were anesthetized with an overdose of chloroform and sacrificed at 30 minutes, 5 hours and 10 hours post injection. The relative GnRH receptor-II mRNA expression levels in different tissues as a result of ovaprim injection were assessed at 30 minutes, 5 hours and 10 hours, based on the pulsatile nature of GnRH release and episodic secretion of gonadotropic hormones from the anterior pituitary gland in order to control reproductive functions (Krsmanovic et al., 2003). Tissues were harvested from the sham-injected (control) and ovaprim-injected (treated) groups.

\subsection{RNA isolation and RT-PCR}

Ovary, testis, kidney and liver tissues were collected from the ovaprim-injected and control fish. $100 \mathrm{mg}$ of tissue samples were frozen quickly in liquid nitrogen and total RNA was isolated using TRI reagent (SIGMA) following manufacturer's instructions. After extraction, the RNA was quantitated and assessed for purity by spectrofluorometric measurements and stored at $-80^{\circ} \mathrm{C}$ until used for reverse transcription-PCR assays. First-strand cDNAs were synthesized from $5 \mu \mathrm{g}$ total RNA using oligo dT primers (First Strand Synthesis kit, Bangalore Genei, India) and stored at $-20^{\circ} \mathrm{C}$ until used for PCRs. Gene specific primers of the GnRH-receptor II of the African catfish, a close relative of the Indian catfish, were used to determine the expression pattern of the receptor at extra-pituitary sites in C. batrachus (Bogerd et al., 2002). The expression of GnRH-receptor I was not detectable in the African catfish ovary, and hence was not selected for ovaprim-mediated studies in the Indian variety. The sequences of primers used were as follows: cfGnRH-RII-Fw: 5'-TTTATCTTCAGAGCTATCAAAGCAGAA-3' and cfGnRH-RII-Rv: 5'- ACACCGGCGCAACAAGA-3'. PCR was performed using a PCR master mix (Bioline, UK; Cat. No. BIO-25005) and an annealing temperature of $55^{\circ} \mathrm{C}$ for 40 cycles. The PCR product was visualized by $1 \%$ agarose gel electrophoresis. The samples were run in triplicates for statistical analysis. An initial experiment was carried out to confirm the presence or absence of the GnRH receptor-II in different tissues of the Indian catfish, in absence of ovaprim injections. Subsequent 
experiments were carried out to detect the expression of the receptor following ovaprim administration and in sham-injected animals.

\subsection{Histological staining and light microscopic studies}

Tissues (ovary, liver, kidney, and testes) from control and treated fish were dissected out and fixed in aqueous Bouin fluid, dehydrated and cleared in cedar wood oil. Tissues were embedded in paraffin wax and cut at $5-\mu \mathrm{m}$ thickness. Tissue sections were stained with hematoxyline and eosin and mounted in DPX. Digital photographs were taken at 10X and 40X magnifications.

\subsection{Statistical Analysis}

All individual experiments were carried out three times independently in order to ensure repetition of results. Data were analyzed statistically by one way analysis of variance followed by Tukey's post hoc test and students' t-test (Snedecor and Cochran, 1971) to ascertain the degree of significance between experimental groups.

\section{Results}

\subsection{Tissue distribution of GnRH receptor-II mRNA}

Presence of GnRH receptor transcripts in sites other than the hypothalamo-pituitary-gonadal axis has been demonstrated in the African catfish (Bogerd et al., 2002; Habibi et al., 1994). Studies have shown that the cfGnRH-II mRNA is ubiquitously expressed in the brain, heart, pituitary and the head-kidney, in addition to the ovary and testis. Subsequently, we investigated the expression of the GnRH receptors in the ovary, a prime target of GnRH. In order to determine whether there were any inter-specific variations, we also investigated the expression of the GnRH receptors in the testis, heart, brain, liver and head-kidney as controls for the experiment. The results indicated the presence of GnRH receptor-II mRNA in the ovary, testis and heart, where maximum expression was observed in the ovary and minimum in the heart (Figure 1A). Interestingly, and contrary to the findings in the African catfish, considerable expression of GnRH receptor-II was detected in the liver but there was no expression in the head-kidney and brain. It was confirmed that no genomic DNA was amplified in this experiment, since some of the tissues were negative with respect to GnRH receptor-II. The relative GnRH receptor-II distribution in different tissues has been represented graphically following densitometric analysis of the band intensities of three independent experiments (Figure 1B).

\subsection{Ovaprim down-regulates the expression of GnRH receptor-II}

In order to determine the relative GnRH receptor-II mRNA expression levels in different tissues as a result of ovaprim injection, sham- and ovaprim-injected catfish were sacrificed at 30 minutes, 5 hours and 10 hours. The 5-hour time point was selected on the basis of previous reports, where it has been shown that maximum efficiency of ovaprim-induced spawning occurs between 4-6 hours (Sridhar et al., 1998). The 10-hour time point was selected since most stripping operations are carried out after 10 hours for the eggs to be fertilized (Nwokoye et al., 2007), hence the effect of the drug should be minimal at that time point. The results demonstrated that compared to tissues of the sham-injected animals, viz. ovary, testis, heart and liver, expressions of the GnRH receptor-II mRNA in all ovaprim-treated tissues were down regulated after treatment with ovaprim (Figures 2 $\mathrm{A}, \mathrm{B})$. Interestingly, down-regulation of the receptor expression was observed in a time-dependent manner, where almost 50\% down regulation was observed at 5 hours and almost no expression of the receptor was observed 10 hours after ovaprim treatment in any of the tissues. In contrast, ovaprim generally takes 6-7 hours to induce almost $100 \%$ ovulation in carps and hence, indicates that the capacity of ovaprim to increase the GnRH receptor expression exists during that time period (data not shown) (Mudnakudu et al., 1989).

\subsection{Light micrographic images indicate alterations in ovaprim-injected tissues}

It is well-established that GnRH acts through the GnRH receptors on the target organs and consequently affects the tissue architecture of the target organs (Habibi et al., 1988; Pati and Habibi, 1992). Since ovaprim displayed reduced potency to induce spawning in the Indian catfish and led to down-regulation of the GnRH receptor-II in the ovary, we attempted to investigate if the results could be correlated with concomitant changes in the histological architecture of the ovary, along with those of the testis, liver and head-kidney. The results indicated that the ovaprim-treated ovary showed prominent features of spawning which included perinucleolar, previtellogenic, yolked oocytes, atretic structures and postovulatory follicles. Maximal changes were observed in the 10-hour group and the size of mature follicles increased in the treated group, with a concomitant decrease in the size and number of the immature follicles (Figure 3). The most significant changes in the testis were a 2-fold increase in the diameter of the seminiferous tubules, as determined by occulometry, and migration of the developing germ cells towards the lumen of the tubules (Figure 4). In addition, the germinal epithelial layer also showed considerable thickening. The liver showed an increased concentration of Kupffer cells in the central vein 
region and a prominent presence of eosinophilic foci/macrophage aggregates (Figure 5). The kidney, which did not express GnRH receptor-II as evident from RT-PCR data, also did not demonstrate any change in tissue structure even after 10 hours of ovaprim injection (Figure 6).

\section{Discussion}

It is well established that in vertebrates, GnRH acts via GnRH receptors in the pituitary and leads to the release of pituitary gonadotropins, which regulate vertebrate reproduction (Dixon, 2001). Three distinct evolutionary forms of GnRH have been found: a hypothalamic form, which varies in primary structure among species; a completely conserved mesencephalic form, chicken GnRH-II; and a telencephalic form, salmon GnRH (Fernald and White, 1999). In addition, it has also been demonstrated that the sites of GnRH synthesis are not restricted to the brain, and possible functions for GnRHs synthesized at widespread loci have been reported (Millar et al., 1997).

Although there is no data till date regarding the expression and distribution of GnRH receptors in the Indian catfish, the same has been evaluated for the African variety (C. gariepinus), where only the species-specific, hypothalamic form of GnRH, catfish GnRH and the conserved mesencephalic cGnRH-II form have been identified by peptide chemistry (Bogerd et al., 1992). GnRH-binding sites have also been characterized in the African catfish ovary, which suggests that GnRH receptors are expressed at extrapituitary sites, and that GnRHs, in addition to their gonadotropin-releasing activity, may affect the function of other organs in catfish (Bogerd et al., 2002). Primers specific to the GnRH-receptor II of the African catfish, a close relative of the Indian catfish, were used to determine the expression pattern of the receptor in the ovary and at extra-pituitary sites in $C$. batrachus. GnRH-receptor I primers were not selected because of absence of detectable expression levels in the African catfish ovary, which is a primary target organ for ovaprim (Bogerd et al., 2002). Our studies have revealed the presence of GnRH-receptor II in the ovary, testis, liver and heart. The expression was not prominent in the head kidney and undetectable amounts of the receptor in the total brain extract could be attributed to dilution of expression sites. The most prominent expression was seen in the ovary, which conforms to that observed in the African catfish (Bogerd et al., 1992). This observation suggests that in addition to their gonadotropin-binding activity and stimulating factors directly related to the reproductive cascade, GnRH may affect other functions in the ovary of the catfish, like oocyte meiosis and/or gonadal steroidogenesis, which is prominently seen in the goldfish and in carps (Sokolowska et al., 1984; Lin et al., 1986). It is also known that in the catfish, the species-specific, hypothalamic form of GnRH, and the conserved mesencephalic GnRH-II form have been identified by peptide chemistry (Bogerd et al., 1992); thus, the appearance of two amplicons in the ovary could possibly be due to expression of the two species-specific forms of the receptor in the Indian catfish.

Ovaprim is a drug that is popularly used for induced breeding in fish (Peter et al., 1988). Although it is successful in all major carps, the success rate has been rather low in catfish. In an attempt to investigate the rationale behind the low success rate in Clarias batrachus, we studied the effect of ovaprim on the distribution of GnRH receptors in the Indian catfish, especially on its expression pattern in the ovary, in response to ovaprim injection. Time-dependent expression profiling analysis revealed that ovaprim injection decreased the expression of GnRH receptor-II mRNA in Clarias batrachus ovary in a time-dependant manner. This observation may be attributed to a specific negative feedback mechanism imposed by the hormone-analog on the hypothalamo-pituitary-gonadal axis, which activates a signal that downregulates the expression of the GnRH receptors in the ovary. A similar time-dependent decrease in the expression of the receptor was observed in the liver and testis. However, the expression pattern did not show any change in the heart, indicating either an alternate signaling pathway or an inactive functional status of GnRH receptors of this organ. However, since our major objective was to determine the reduced potency of ovaprim in inducing spawning in the Indian catfish, the prominent and rapid decrease in GnRH receptor-II mRNA in the ovary could be the primary reason for the low success rate of ovaprim-induced spawning in this species. Downregulation the GnRH receptor-II in the ovary in response to ovaprim leads to decreased folliculogenesis, as evident by the decrease in the size and number of immature follicles, and subsequently reduces ovulation in this species. The histological changes in the testis and liver indicate an increase in their activity in response to ovaprim injection, and the fact that there was no change in the histology of the kidney is probably due to the absence of GnRH receptor-II in the head kidney, as indicated by RT-PCR analysis.

Treatment of fish with spawning agents like ovaprim has been successful in carps, goldfish and others. However, the effect of ovaprim has not been as pronounced in the Indian catfish. Our studies have demonstrated that this decrease in spawning efficiency may be attributed to a decrease in the expression of GnRH-receptor II in the catfish ovary, leading to a concomitant decrease in the development and maturation of primary follicles and subsequent ovulation. Further sequencing, classification and distribution the GnRH receptors in C. batrachus 
will help elucidate the precise role of these receptors in the gonadal and extra-gonadal organs in this species and help manipulate the reproductive fecundity of catfish by combinational drug administration.

\section{Acknowledgement}

We thank Prof. B.R. Maiti for his critical evaluation of this manuscript and valuable suggestions. We are indebted to University Grants Commission, New Delhi, India, and Dr. A. Sharma and Dr. S. Ghosh for providing funds to U.C. and M.C., respectively. We are also grateful to the Department of Science and Technology, New Delhi, India, for providing infrastructure support through the FIST programme.

\section{References}

Bogerd, J., Diepenbroek, W.B., Hund, E., Oosterhout, F.V., Teves, A.C.C., Leurs, R., \& Blomenröhr, M. (2002). Two Gonadotropin-Releasing Hormone Receptors in the African Catfish: No Differences in Ligand Selectivity, but Differences in Tissue Distribution. Endocrinol, 143, 4673-4682.

Bogerd, J., Li, K.W., Janssen-Dommerholt, C., \& Goos, C.H. (1992). Two gonadotropin-releasing hormones from African catfish (Clarias gariepinus). Biochem Biophys Res Commun, 187, 127-134.

Dixon, A. (2001). The evolution of neuroendocrine mechanism regulating sexual behaviour in female primates. Reprod Fertil Dev, 13, 599.

Dupree, H.K., \& Huner, J.V. (1984). United States Department of the Interior, Fish and Wildlife Service. Third Report to the Fish Farmers.

Fernald, R.D., \& White, R.B. (1999) Gonadotropin-releasing hormone genes: phylogeny, structure, and functions. Front. Neuroendocrinol, 20, 224-240.

Habibi, H.R., Pati, D., Ouwens, M., Goos, H.J.T. (1994). Presence of gonadotropin-releasing hormone (GnRH) binding sites and compounds with GnRH-like activity in the ovary of African catfish, Clarias gariepinus. Biol Reprod, 50, 643-652.

Habibi, H.R., Van Der Kraak, G., Bulanski, G.E., \& Peter, R.E. (1988). Effects of teleost GnRH on reinitiation of oocyte meiosis in goldfish in vitro. Am J Physiol, 225, 268-272.

Habibi, H.R., Van Der Kraak, G., Fraser, R., \& Peter, R.E. (1989). Effect of a teleost GnRH analog on steroidogenesis by the follicle-enclosed goldfish oocytes, in vitro. Gen Comp Endocrinol, 76, 95-105.

Kelley, C.D., \& Lee, C.S. (1986). Artificial propagation. In: Lee C-S, Gordonand MS, Watanabe WO (Eds.), Aquaculture of milkfish (Chanos chanos). State of the art. Oceanic Institute, Hawaii, 83-116.

Krsmanovic, L.Z., Mores, N., Navarro, C.E., Arora, K.K., \& Catt, K.J. (2003). An agonist-induced switch in G protein coupling of the gonadotropin-releasing hormone receptor regulates pulsatile neuropeptide secretion. Proc. Natl. Acad. Sci, 100(5), 2969-2974.

Kungvankij, P., Tiro, L., Pudadera, B.P., \& Potestas, I.O. (1986). Induced spawning and larval rearing of grouper (Epinephelus salmoides Maxwell). In: J.L. Maclean, L.B. Dizon and L.V. Hosillos (Eds.), The First Asian Fisheries Forum. Asian Fisheries Society, Manila, Philippines.

Lee, C.S., Tamaru, C.S., Miyamoto, G.T., \& Kelley, C.D. (1987). Induced spawning of grey mullet (Mugil cephalus) by LHRHa. Aquaculture, 62, 327 - 336.

Lin, H.R., Kraak, G.V.D., Liang, J.Y., et al. (1986). The effects of LHRH analogous and drugs which block the effect of dopamine on gonadotropin secretion and ovulation in fish cultured in China. In: R. Billard and J. Marcel (Eds.) Aquaculture of Cyprinids. INRA, Paris, France, 139-150.

Marte, C.L., Sherwood, N.M., Crim, L.W., \& Harvey, B. (1987). Induced spawning of maturing milkfish (Chanos chanos forsskal) with gonadotropin-releasing hormone $(\mathrm{GnRH})$ analogues administered in various ways. Aquaculture, 60, 303-310.

Millar, R.P., Troskie, B., Sun, Y.M., et al. (1997). Plasticity in the structural and functional evolution of GnRH: a peptide for all seasons. In: Kawashima S, Kikuyama S. (Eds.) Advances in Comparative Endocrinology. Proc. 13th International Congress of Comparative Endocrinology, Bologna, Italy, 15-27.

Mudnakudu, C.N., Rao, K.G., Jayanna, R.N., Parker, N.C., Varghese, T.J., Keshavanath, P., Shetty, H.P.C. (1989). Induced spawning of Indian Mirror Carps through single application of ovaprim. Proc. Second Asian Fisheries Forum, Tolyo, Japan, 990.

Ngamvongchon, S., Pawaputanon, O., Leelapatra, W., \& Johnson, W.E. (1988). Effectiveness of LHRH analogous for the induced spawning of carp and catfish in Northeast Thailand. Aquaculture, 74, 35 - 40. 
Nwokoye, C.O., Nwuba, L.A., \& Eyo, J.E. (2007). Induced propagation of African clariid catfish, Heterobranchus bidorsalis (Geoffrey Saint Hillarie, 1809) using synthetic and homoplastic hormones. African Journal of Biotechnology, 6 (23), 2687-2693.

Nwokoye, C.O., Nwuba, L.A., \& Eyo, J.E. (2007). Induced propagation of African clariid catfish, Heterobranchus bidorsalis (Geoffrey Saint Hillarie, 1809), using synthetic and homoplastic hormones. Afr. J. Biotech, 6, 2687-93.

Pati, D., \& Habibi, H.R. (1992). Characterization of gonadotropin-releasing hormone (GnRH) receptors in the ovary of common carp (Cyprinus carpio). Can J Physiol Pharmacol, 70, 268-274.

Peter, R.E., Lin, H.R., Van Der Kraak, G. (1988). Induced ovulation and spawning of cultured freshwater fish in China: Advances in application of GnRH analogues and dopamine antagonists. Aquaculture, 74, 1-10.

Piper, R.G. (1989). United States Department of the Interior, Fish and Wildlife Service. Fish Hatchery Management.

Richardson, A. (1988). Hatchery Manual for the White Sturgeon Acipenser transmontanus with Application to Other North American Acipenseridae. Cooperative Extension, University of California, Division of Agriculture and Natural Resources.

Robinson, R.R., White, R.B., Illing, N., Troskie, B.E., Morley, M., Millar, R.P., \& Fernald, R.D. (2001). Gonadotropin-Releasing Hormone Receptor in the Teleost Haplochromis burtoni: Structure, Location and Function. Endocrinol, 142, 1737-1743.

Rottmann, R.W., Shireman, J.V., \& Chapman, F.A. (1991). Introduction to Hormone-Induced Spawning of Fish. SRAC Publication, No. 421.

Sokolowska, M., Peter, R.E., Nahorniak, C.S., et al. (1984). Induction of ovulation in goldfish Carassius auratus by pimozide and analogous of LHRH. Aquaculture, 36, $71-83$.

Sridhar, S., Vijayakumar, C., \& Haniffa, M.A. (1998). Induced spawning and establishment of a captive population for an endangered fish, Ompok bimaculatus in India. Current Sci, 75(10), 1066.

Staff, F. (1983). Alaska Department of Fish and Game, Division of Fisheries Rehabilitation, Enhancement and Development. Fish Culture Manual.

Syndel International Inc. Induced spawning of cultured fish using Ovaprim. [Online] Available: http://www.syndel.com/spawning/ovaprim_product_information.html.

Thalathiah, S., Ahmad, A.O., \& Zaini, M.S. (1988). Induced spawning techniques practiced at Batu Berendam, Malaka, Malaysia. Aquaculture, 74, 23 - 33.

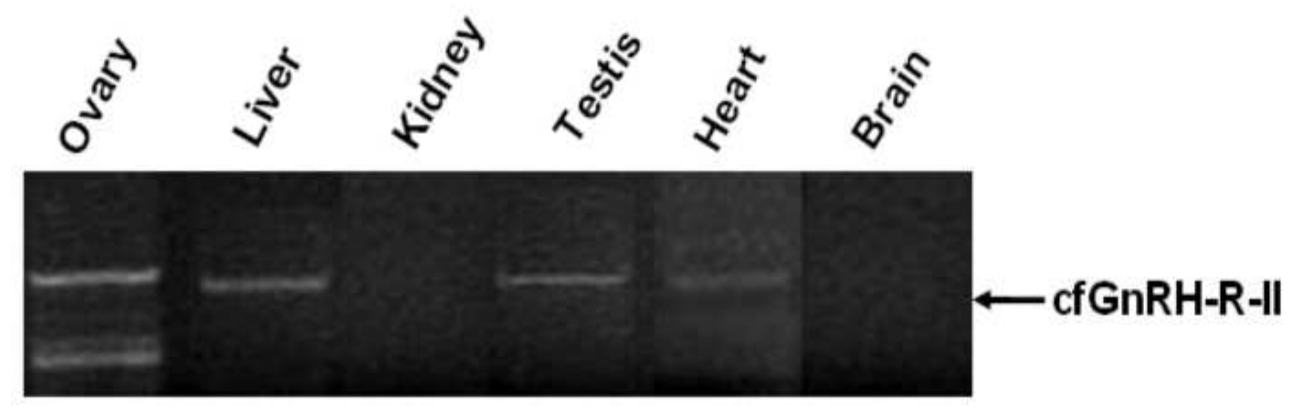

Figure 1A. Relative catfish GnRH receptor-II mRNA levels in different tissues

Expression levels were analyzed by RT-PCR using primers based on C. gariepinus GnRH receptor-II (see Materials and Methods). Maximum expression was observed in the ovary and minimum in the heart. Expression was not detected in the kidney and whole brain extracts. 


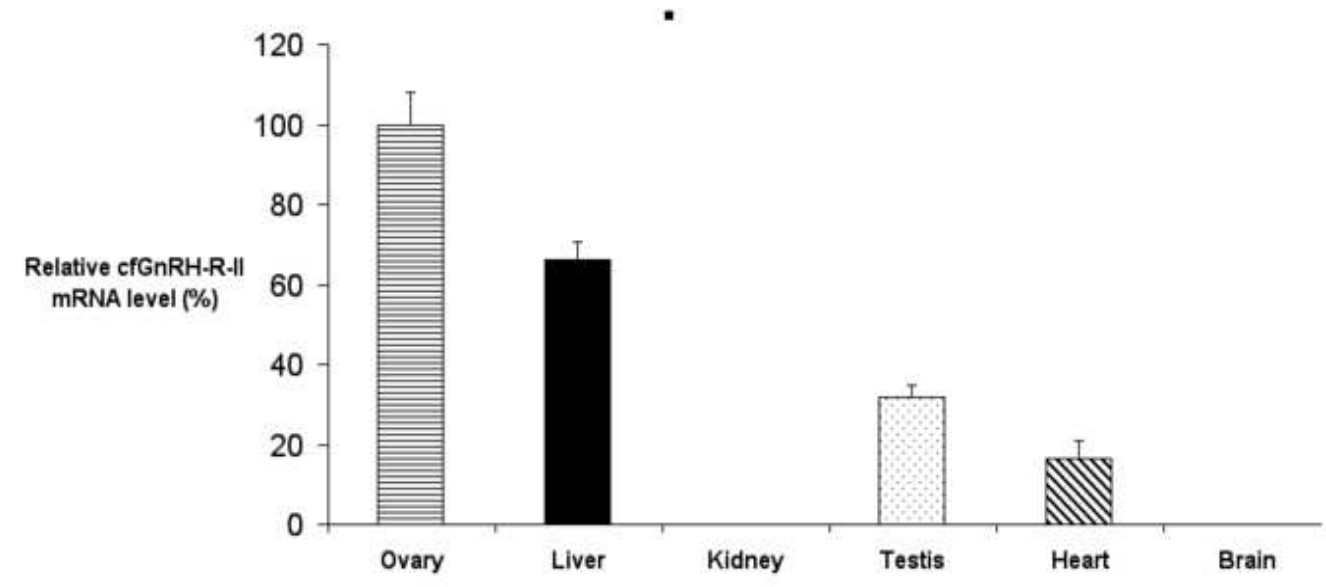

Figure 1B. Graphical representation of the relative levels of GnRH receptor-II mRNA in different tissues of $C$. batrachus using RT-PCR

The experiment was repeated in triplicates and the mRNA expression was measured. The data was analyzed and represented as per standard statistical methods. Maximum distribution of GnRH-receptor II mRNA was present in ovary; set at $100 \%$.
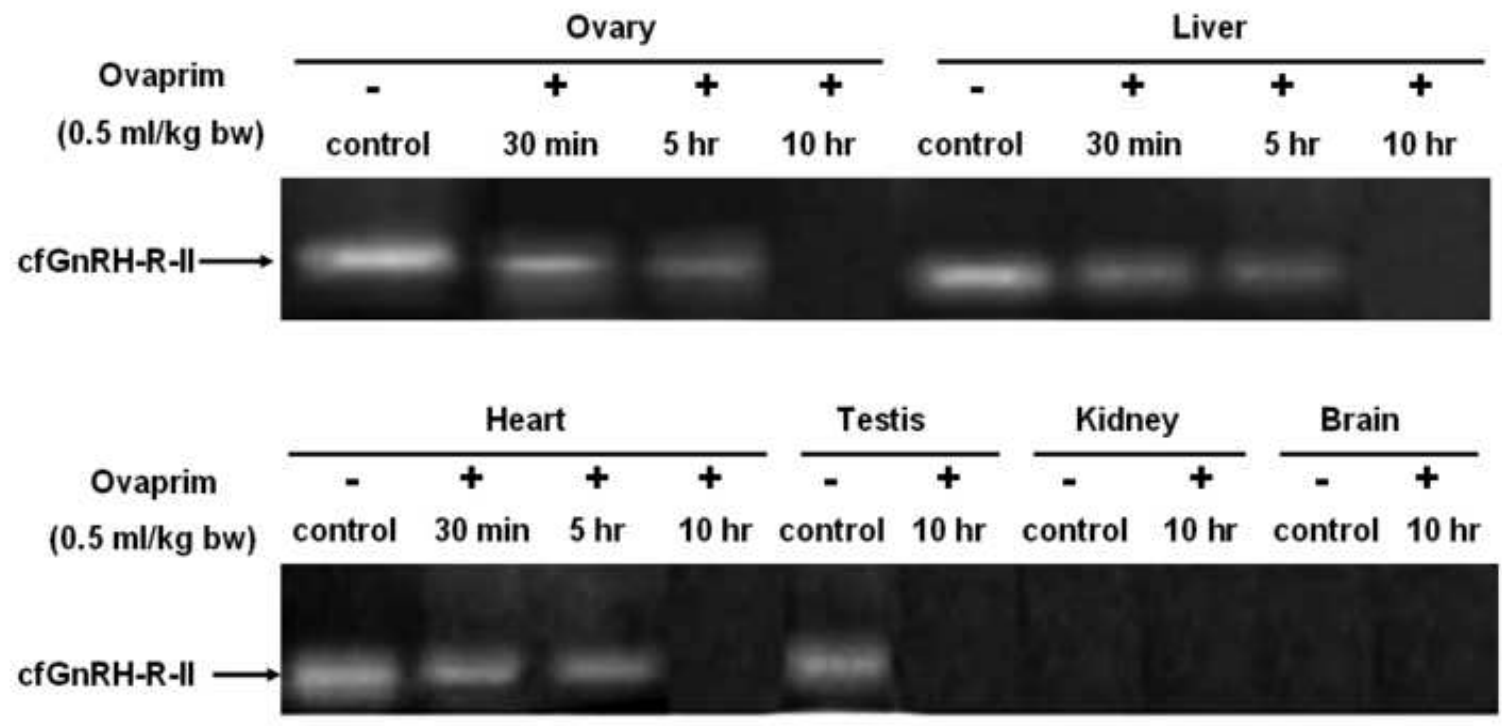

Figure 2A. Effect of ovaprim treatment on different tissues of the Indian catfish

The expressions of GnRH receptor-II mRNA in C. batrachus after ovaprim treatment at different time intervals were compared with corresponding control tissues. con, control; $30 \mathrm{~min}, 30$ minutes treatment; $5 \mathrm{hr}$, 5 hour treatment and $10 \mathrm{hr}, 10$ hour treatment of ovary, liver, heart, testis, kidney and brain. Significant time-dependant changes were observed in most tissues after ovaprim treatment, except for the heart. 


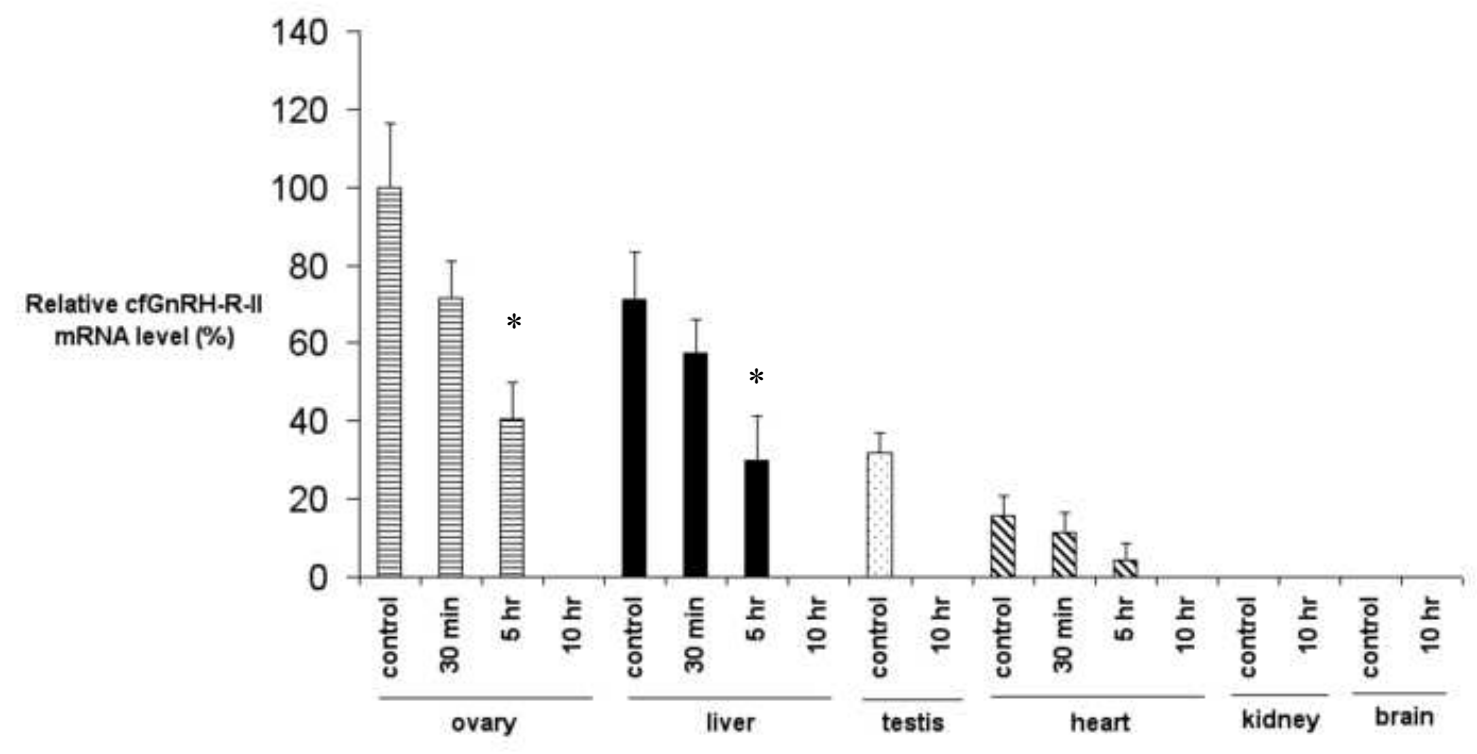

Figure 2B. Graphical representation of the levels of GnRH receptor-II mRNA in different tissues of C. batrachus after treatment with ovaprim

Maximum distribution of GnRH receptor-II mRNA was present in ovary; set at $100 \%$. Significant differences with the control tissues (performed in triplicates) were determined with Student's $t$-test, $P<0.05$.
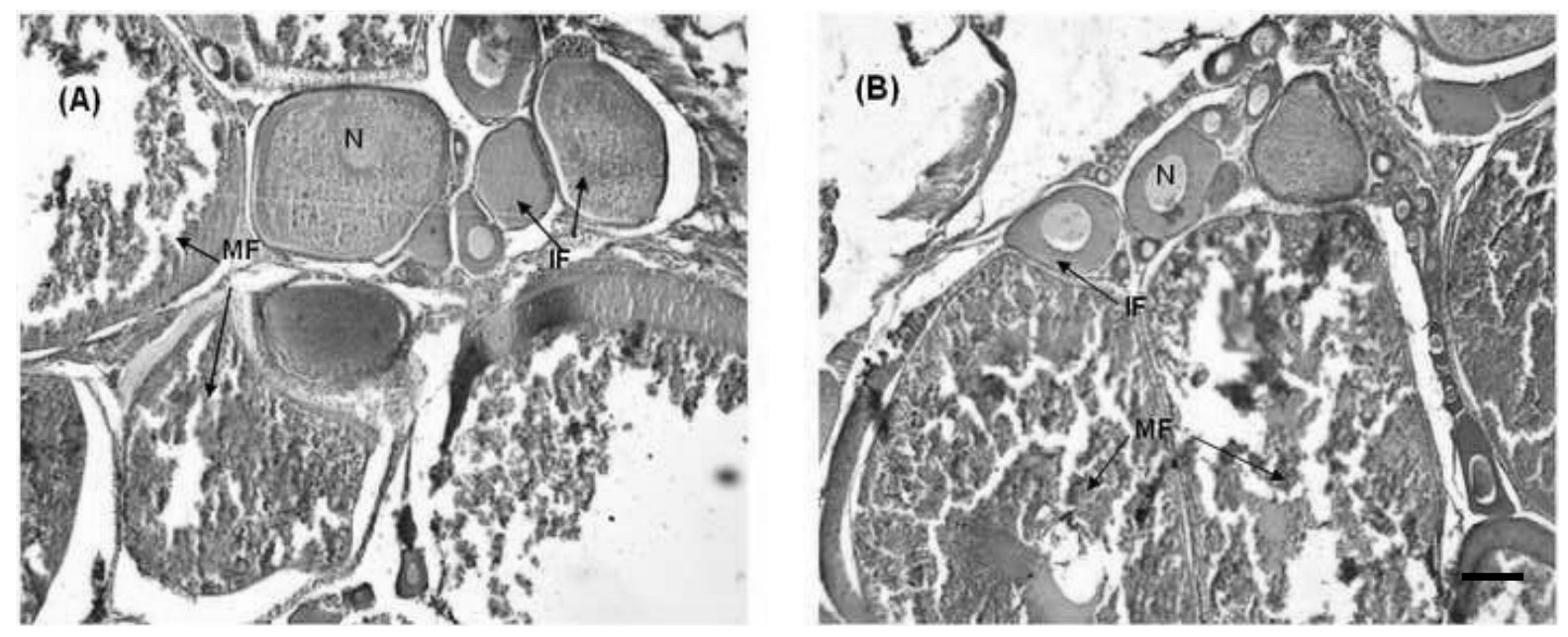

Figure 3. Representative histological sections of the C. batrachus ovary

(A) Control Ovary (B) Treated Ovary. Treated ovary shows increased signs of increased activation of mature follicles, as indicated by hyperplasia of follicular tissues, and a significant decrease in number and size of immature follicles indicated by the arrows. N, Nucleus; IF, Immature Follicle; MF, Mature Follicle. Bar, $400 \mu \mathrm{m}$. 

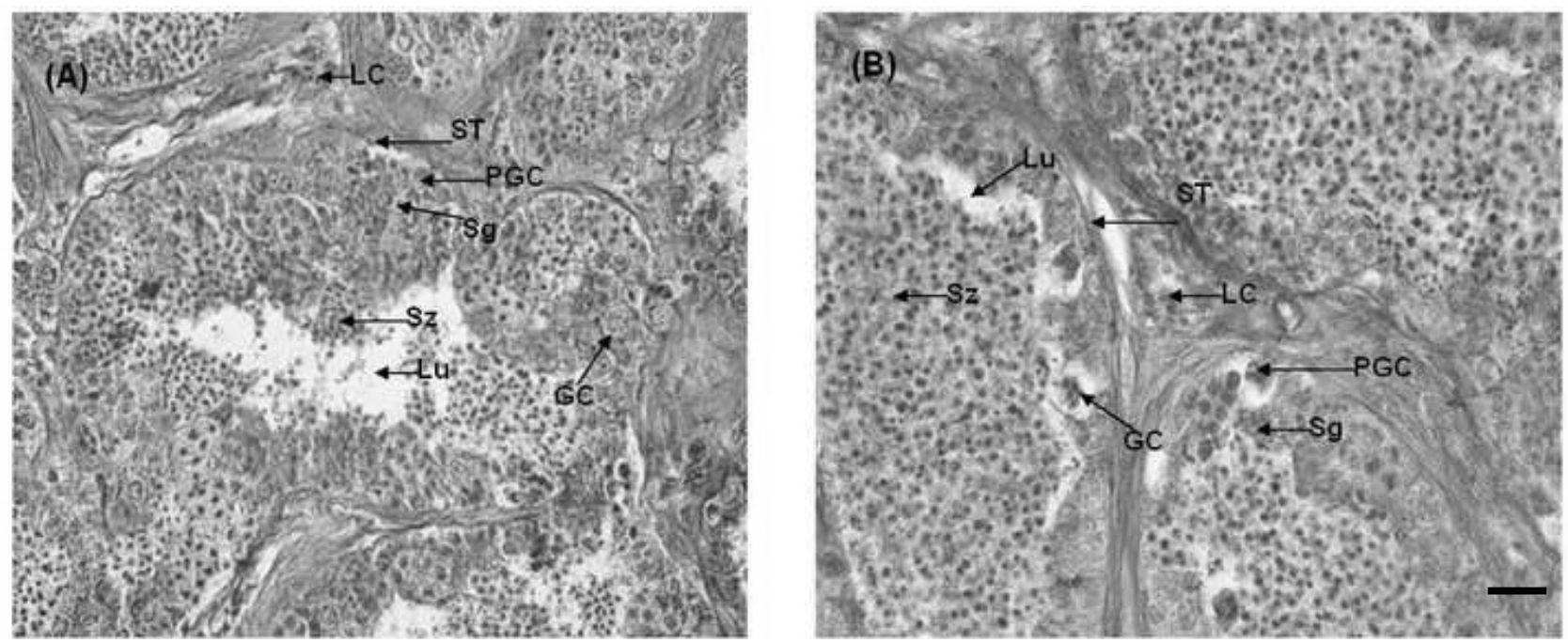

Figure 4. Transverse section of the $C$. batrachus testis, middle region

(A) Control Testis (B) Treated Testis. Treated testis shows increased signs of spermatogenesis and secretory activity. LC, Leydig Cell; ST, Seminiferous Tubule; PGC, Primordial Germ Cell; Sg; Spermatogonia; Sz, Spermatozoa; GC, Germinal Cyst; Lu, Lumen. Bar, $250 \mu \mathrm{m}$.
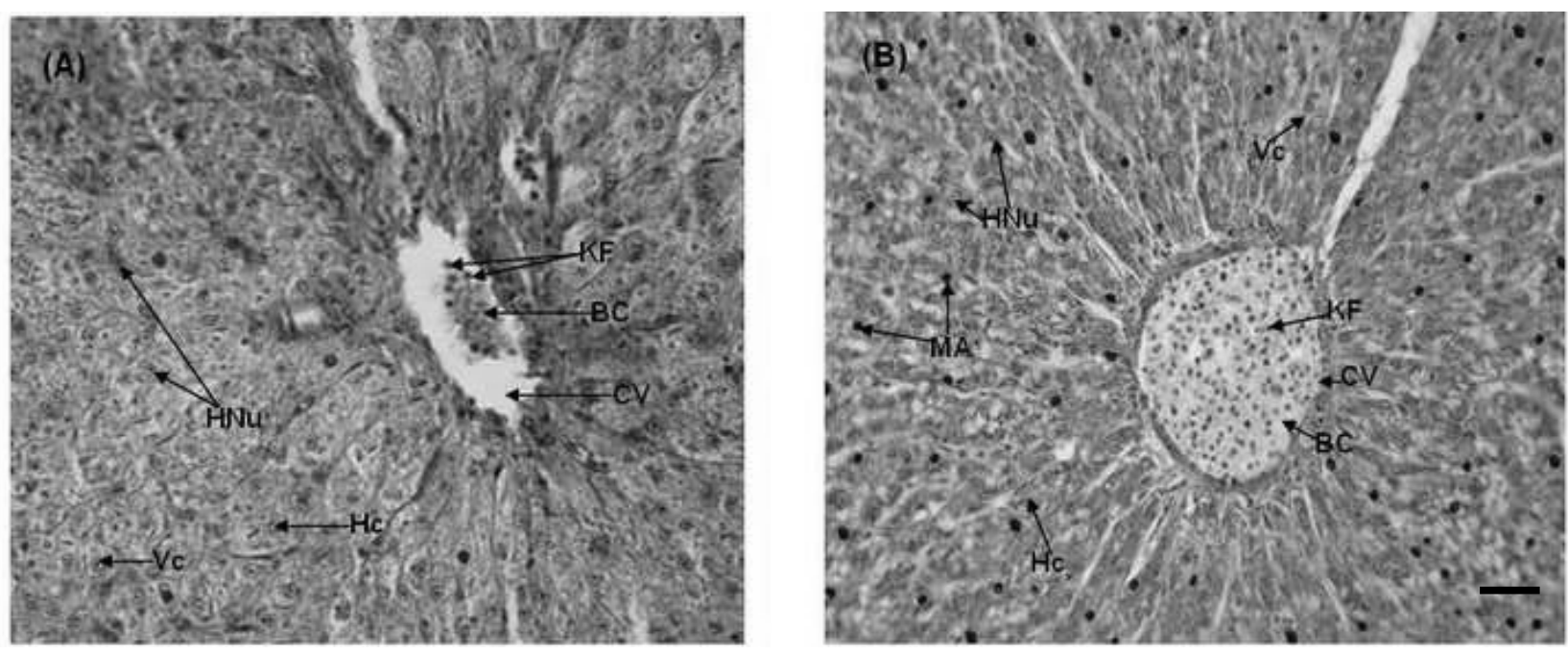

Figure 5. Changes in the liver of ovaprim-treated C. batrachus liver

(A) Control Liver (B) Treated liver. Treated liver shows increase signs of metabolism and non-specific immunological response due to ovaprim injection. Hc, Hepatocytes; $\mathrm{HNu}$, Hepatocyte Nucleus; CV, Central Vein; BC, Blood Cells, KC, Kupffer Cells; Vc, Vesicles. Bar, $250 \mu \mathrm{m}$. 

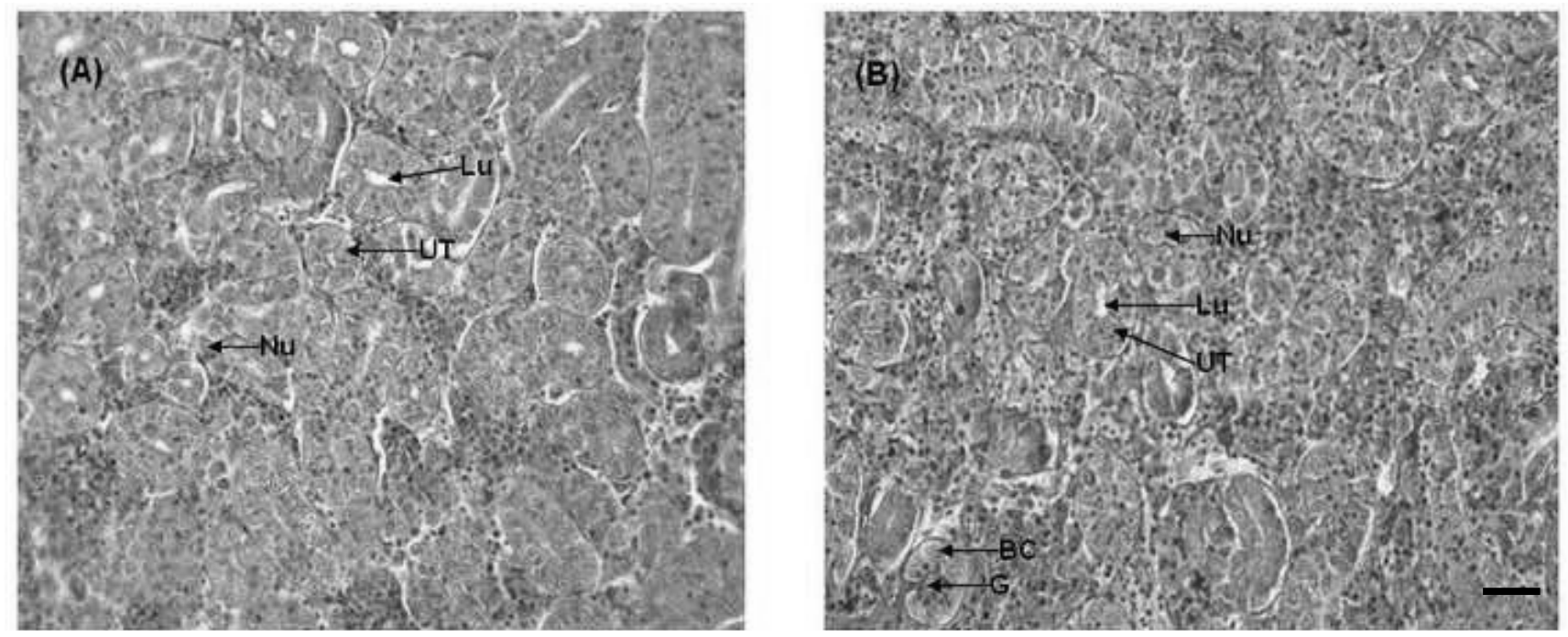

Figure 6. Transverse section of C. batrachus kidney, middle region

(A) Control Kidney (B) Treated Kidney. Kidney remained fairly unaffected in response to ovaprim treatment. UT, Uriniferous tubule; Lu, Lumen; Nu, Nucleus; BC, Bowman's capsule; G, Glomerulus. Bar, $250 \mu \mathrm{m}$. 